\title{
Reducing municipal waste through promoting integrated sustainable waste management (ISWM) practices in Surabaya city, Indonesia
}

\author{
D. G. J. Premakumara, M. Abe \& T. Maeda \\ Institute for Global Environmental Strategies, Japan
}

\begin{abstract}
Solid waste management is considered to be one of the most serious environmental issues confronting urban areas in developing countries. In keeping with global trends, many cities are focused on integrated approach based on the 3Rs (reduce, reuse and recycle) and trying to reduce the amount of waste generation at source rather than later at the end-of-pipe. However, these efforts are still very limited with a mix of results and relatively few efforts have been made to regulate organic materials that usually comprise over $50 \%$ of the total waste generation in the cities. Despite the fact, Surabaya city, the second largest in Indonesia with a population of three million people has shown to have succeeded in reducing its municipal waste generation by more than $20 \%$ over the last four years, introducing waste separation and reduction activities at household, community-managed waste collection and polluter pay principle, promoting composting practice by setting up composting centers and distributing thousands of compost baskets to residents, and organising community cleanup campaigns and waste recycling activities with local NGOs, private sector (formal and informal) and the media. Surabaya's achievement exemplifies how a city can reduce a large amount of waste in a short period of time spending limited budget by establishing Integrated Sustainable Waste Management System (ISWM), which seeks institutional, social, environmental, political, technical and financial aspects while emphasising the critical role of involving various stakeholders, covering waste prevention and resource recovery, including interactions with other urban systems and promoting and integrating different habitat scales from household, neighbourhood to city.

Keywords: integrated sustainable waste management, composting, recycling, participation, informal sector, community-based organisations.
\end{abstract}




\section{Introduction}

Solid waste management is considered to be one of the most serious environmental issues confronting urban areas in developing countries (UNHABITAT [1]). Rapid urbanisation, increasing industrialisation, rising incomes and more sophisticated form of consumerism are leading to an increase in the amount of solid waste (Casanova [2]), which is in turn creating enormous challenges for municipal authorities in providing effective waste collection services to its residents. The Global Waste Management Market Assessment (2007) indicates that municipal solid waste generation worldwide in 2006 at two billion tonnes with a 37\% increase forecast by 2011 Key Note Publication Ltd [3]. The daily waste generation in urban areas of Asia was about 0.7 million tonnes in 1999 and it is expected to reach about 1.8 million tonnes per day by 2025 (World Bank [4]). It is common for many municipalities in developing countries to spend $20-50 \%$ of their available budget on solid waste management, even though $30-60 \%$ of all the urban solid wastes remain uncollected and less than $50 \%$ of the population is served (UNEP [5]). In addition, many landfills in developing countries are poorly designed and uncontrolled, which creates serious environmental impacts (Zurbrugg et al. [6]). Further, existing landfills have almost reached their maximum capacity and finding new sites that offer environmentally sound and economically viable options is becoming increasingly difficult.

To address these issues, many cities in developing countries focus on establishing an integrated solid waste management system based on the $3 \mathrm{Rs}$ and trying to reduce the amount of waste generation at source rather than later at the end-of-pipe. However, these efforts are still very limited with a mix of results and relatively few efforts have been made to regulate organic materials that usually comprise over $50 \%$ of the total waste generation in the cities (Dulac [7]). The legitimate question arises how cities in developing countries can be deled with municipal solid waste in an efficient, effective and sustainable manner.

Despite the fact, Surabaya city, the second largest in Indonesia with a population of three million has shown succeed in reducing its municipal waste generation by more than $20 \%$ over the last four years, introducing waste separation and reduction activities at household, community-managed waste collection services and polluter pay principle, promoting composting practice by setting up composting centres and distributing thousands of compost baskets to its residents, and organizing community cleanup campaign and waste recycling activities with local NGOs, private sector (formal and informal) and the media.

This paper therefore aims to examine the key factors in the success of the Surabaya's solid waste management system by elaborating the Integrated Sustainable Waste Management (ISWM) framework. It is structured as follows: Section 2 gives a general concept of the ISWM and its relevance as an analytical framework. Then, section 3 analyses the municipal solid waste management in Surabaya city and discusses the city's new waste management system in establishing material recycling society, promoting compost utilisation. Section 4 analyses in details the key factors supported for the successful implementation of 
Surabaya's new waste management system based on the ISWM framework, taking into account the stakeholder participation, waste prevention and resource recovery through interaction of other urban systems and integration of different habitat scales, and integration of different aspects of sustainability rather than overemphasis on technical aspects alone. Finally, section 5 concludes by drawing lessons learned from the evidence and discussions. The paper provides both general information and case study analysis based on the information gathered through literature review, field observations and discussions with the relevant stakeholders.

\section{The concept of integrated sustainable waste management (ISWM)}

\subsection{Moving towards sustainable solutions for municipal solid waste management}

Municipal solid waste is commonly defined as household waste or domestic waste and wastes of a similar nature generated by commercial, industrial, public institutions and from public spaces, such as streets, parks and gardens [5]. In the past, municipal solid waste management was seen largely as a technical problem with engineering solutions [1]. It was primarily included waste collection, land disposal and incineration. However, this thinking has changed during the 1980s and 1990s, when it became apparent that land filling and incineration have significant environmental impacts, as well as not enough to deal with the large volumes of solid waste generated in the cities.

Due to these issues and the emergence of the sustainable development concept resulted to foster the idea of sustainable municipal solid waste management. Effective management of municipal solid waste is essential to achieve the sustainable development, as mentioned in Agenda 21: "environmentally sound management of wastes was among the environmental issues of major concern in maintaining the quality of the Earth's environment and especially in achieving environmentally sound and sustainable development in all countries" (Commission on Sustainable Development [8]).

Gertsakis and Lewis [9] suggest that true sustainability will require significant increases in the efficiency of resource use recovering more valuable products from the municipal waste stream. It became apparent that the practice of the $3 \mathrm{Rs}$ is the basic requirement for sustainability in municipal waste management. According to Smith and Scott [10], the waste management hierarchy is a protocol to maximise the recovery options and to minimise disposal through open dumping, limiting negative impact on the environment and natural resources as much as possible is the basis for achieving sustainable waste management.

The sustainable municipal waste management, however, cannot be separated from good governance (Gilbert et al. [11]). It has been shown that municipal authorities could not successfully collect and remove waste without the active cooperation from the service users [1]. Further, cities came to know that the $3 \mathrm{Rs}$ 
technology depend on institutional, governance and policy frameworks, which are highly varied, and complex, and directly related to local conditions. To address these issues, the concept of ISWM was emerged and it identifies the importance of integrating all stakeholders involved in municipal waste management, the elements of the municipal waste management system and aspects of the local context that should be taken into account for achieving sustainable municipal waste management in developing countries (van de Klundert [12]).

\subsection{Integrated sustainable waste management (ISWM) framework}

The ISWM, as shown in Figure 1, is a framework that was first developed by WASTE, a Dutch non-governmental organisation (NGO), and its partners in developing countries in the 1980s, and further developed by the Collaborative Working Group on Solid Waste Management in Low and Middle Income Countries (CWG) in the mid 1990s (Anschutz et al. [13]). Since then, it has become popular as an approach to reach better, more sustainable solutions to municipal waste management in developing countries (Anschutz et al. [14]).

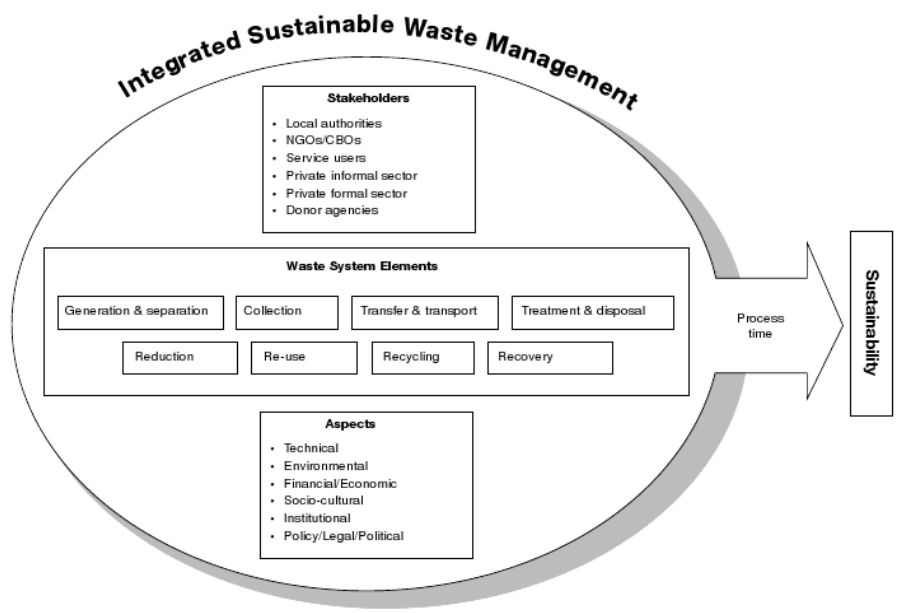

Figure 1: $\quad$ The ISWM framework.

\section{The municipal solid waste management system in Surabaya city}

Surabaya, the second largest city in Indonesia located in eastern Java, serves as an important commercial and industrial capital of the province. The city of three million people generated over 1,500 metric tonnes of municipal waste a day in the following sectors: residential $(68 \%)$, markets $(16 \%)$, commercial/industrial $(11 \%)$, streets and open spaces (5\%) (Medina [16]). Further, the composition of municipal waste generated in Surabaya shows that more than $50 \%$ is organic and 
ideal for composting [16]. The municipal solid waste management of the city consist of three sub-components, including waste collection, transportation and final disposal.

\subsection{Before the project implementation: collection and disposal oriented system}

\subsubsection{Waste collection}

In residential areas, people use different types of storage bins, such as plastic or metal bins and the fixed brick-boxes in front of the house for their household waste storage. People are simply put their garbage into the bins and collectors pick it up, usually the next day. Since the introduction of the community primary collection (Copricol) law in 1980, the collection of waste from residential areas is managed by the Rukun Warga (RW), a neighbourhood association, organises the waste collection scheme in the area collecting fees from households, hiring waste collectors, providing pushcarts, and paying salaries to waste collectors for their services in collecting and transporting waste from household units to transfer stations. Collectors pick up waste from the storage bins using bamboo baskets and take it to a transfer station in handcarts.

Collection of waste from commercial, institutional establishments and from street sweeping is carried out by the Cleansing and Landscaping Department of the municipal authority. The city's waste collection coverage is about $70 \%$ in 2005 , the remaining $30 \%$ is left in the streets, ditches, and open spaces, which blocks the drainage system, contaminates water resources, and results in increased insect and rodent populations (Silas [17]). This situation is at its worst during the rainy season, particularly in low-lying areas where most of the urban poor reside.

\subsubsection{Transfer station}

A transfer station is used to temporally dispose the collected waste from residential areas, before it will transport to the landfill site aiming to reduce the hauling distances for collection trucks, thus lowering transportation costs. Some of the transfer stations are relatively modern, provided with attendants and equipped with mechanical transfers and waste compaction, whereas others are simply a large steel container, concrete bin, and/or open space.

\subsubsection{Transportation}

The collected waste is then transported to the landfill site at Benowo, about 22 miles west, in an area of 40 acres (16 ha). The Cleansing and Landscaping Department of the Municipality is in-charge of transporting the waste accumulated at transfer depots to the final disposal site using municipal containers and trucks. Due to heavy traffic, it takes a long time to reach them, which limits each truck to a maximum of two trips to the disposal site per day. Lacking pollution controls, the landfill site is an open dump and produces smell and odour to environment. Sometimes, it is on fire, particularly in dry seasons and smoke disturb to the people and the environment. It was also estimated that 
the landfill site has a remaining lifespan of five years, and is facing difficulties in finding a new site due to a scarcity of public land.

\subsubsection{Recycling activities}

Surabaya city does not have a municipal recycling programme, but scavengers have been recovering materials from waste for recycling and reuse for decades. According to some studies, scavengers play an important role in the waste management system and the economy of Surabaya, recovering an estimated $30 \%$ of waste generated by the city's residents, creating income opportunities for urban poor and a supply of inexpensive raw materials to industry $[16,17]$ these studies further finds that scavenging can also create problems. For searching reusable and recyclable materials, scavengers spread the waste and sometimes scatter it, making collection more difficult. Direct contact with waste also impacts scavenger health.

\subsubsection{Financial aspects}

The residents pay two separate user fees for waste collection services. One is to the RW for collecting waste from households, and the other is to the city office for transportation and disposal. The monthly fee for the collection of waste from households is decided collectively by the community members and is usually paid together with other community fees. The monthly free for transportation and disposal is calculated by depend on the living condition of the residential area and is paid together with the monthly water supply or electricity bill. Annual user fees collected by the city amount to only half of the $6 \%$ city budget allocated for waste management.

\subsection{Alternative municipal waste management: implementation of resource recovery system}

As a practical solution for the growing issue, a new municipal solid waste management system was developed under a city to city environmental cooperation between Surabaya and Kitakyushu city, Japan in 2004.

\subsubsection{Designing a pilot project in Kampong Rungkut Lor}

The Kitakyushu International Techno-Cooperative Association (KITA) in Kitakyushu and Pusdakota, a local NGO in Surabaya worked together in designing a pilot project in Kampong Rungkut Lor, a low-income neighbourhood located adjacent to the largest industrial area in the city. It was a typical lowincome neighbourhood with about 200 families and the issue of solid waste has often ignited arguments.

In the new system, people were educated to separate organic materials at source, before putting the waste out for collection. The organic waste is then collected separately by Pusdakota twice a week and transported to the nearby composting center. At the center, it is processed using the Takakura Composting Method (TCM), named after a composting expert, Koji Takakura from JPEC, a consulting firm in Kitakyushu, was developed based on the traditional windrow composting method. The composting centre gradually produced a good quality 
of compost in large quantities from separately collected organic waste in two or three weeks and sold to the nearby farmers, private vendors and residents.

Though, programme faced typical constraints in the beginning, such as a lack of community participation and community willingness to separate waste at source, as a result of regular education and public campaigns, as well as the actual visible benefits observed on the ground, the mindset of community members changed, which led to increased participation, discouraged out-side dumping, and resulted in greener and cleaner community. In responding to the community requests, TCM was further modified for use at the household level.

Some households involved making compost from their kitchen waste using a simple compost basket and lessons provided by Pusdakota and used their product for fertilising household gardens. Pusdakota also started to function as a material recycling facility (MRF) by collecting inorganic waste, including recyclable, separately, thus encouraging further waste segregation at source and linking informal recycling business into the municipal waste management system. The pilot experience shows that if it works well, a new waste management system can reduce at least half of waste that needs to be land filled.

\subsubsection{Moving towards city-wide programme}

Surabaya city realised the benefits of the pilot project and took leadership to scale-up the new waste management system by adopting the same composting method in partnership with other local NGOs and a women's group called Pendidikan Kesehahteraan Keluarga (PKK). A system of environmental carders (one carder for every ten households) was established throughout the city to share information on the new waste management system, assist new families in starting household composting, and educate them about the benefits of keeping the environment clean and green. Further, they involved in following-up with monitoring of household composting and troubleshooting by helping families with their composting activities. In 2009, there were about 26,700 environmental carders, covering all 8,800 neighbourhoods in the city.

The households who have general knowledge of the functions of using the compost bins were given free bins and to date, the city has already distributed about 19,000 composting bins, purchasing from Pusdakota (one basket costs about US\$ 10) aiming to support for their voluntary activities. In addition to household composting, the city supports for composting projects at the community level. Currently, 16 community-based composting centres have been functioned in the city to process waste collected from neighbourhoods, markets, streets, and parks. These composting centres have produced about 300 metric tons of compost per month, which are used by the city for parks and street greening programmes.

Since 2005, Surabaya city has been organised a different types of neighbourhood competitions, including Cleanest District Award, Green and Clean Competition, and Free from Waste Competition in partnership with several media partners in the city (Java Pos, JTV (local TV), Suara Surabaya (local radio), Radar Surabaya (local newspaper) to motivate and strengthen community participation in the city's new waste management system, and 
encourage them to improve the neighbourhood environment. About 15 smalland-medium scale recycling businesses have been promoted with the Unilever

Peduli Foundation (UPF), an NGO affiliated with Unilever Indonesia to support the activities of informal waste pickers and their networks. Further, city issued a local regulation No. 1/2006 on community-based solid waste management and incorporated this new strategy in the preparation of the midterm development plans of 2006-2010.

As a result, the waste collection ratio was increased by $90 \%$ and daily average waste generation, which used to be more than 1,500 tonnes a day in and before 2005, has decreased 1,300 tonnes in 2007 and 1,150 tonnes in 2008 as shown in figure 2 . The city has perceptively become cleaner and greener, as acknowledged by many residents and with its achievements honoured with some national and international awards, including the Adipura Award (Clean City Award) from the government of Indonesia for three consecutive years since 2006 and the Energy Global Award from Austria in 2005.

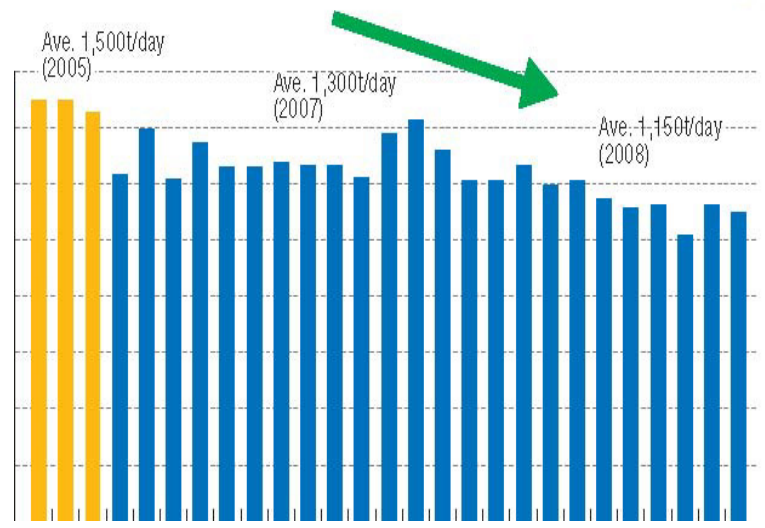

Figure 2: $\quad$ Waste reduction by $20 \%$.

\section{The key factors for the successful implementation of the municipal waste management system in Surabaya city}

This section discusses the key factors for the successful implementation of the municipal solid waste management system in Surabaya city based on the ISWM framework elaborating its three key elements (system elements, stakeholders and aspects) that need to be addressed for municipal waste management system to work well and to work sustainably over time.

\subsection{Integration of waste management system elements}

Surabaya's municipal waste management system has been proved effective in reducing a significant amount of waste generation in a short period of time by establishing waste separation at source, neighbourhood-managed waste 
Table 1: $\quad$ Municipal waste management system at habitat scales.

\begin{tabular}{|c|c|c|}
\hline Habitat scale & $\begin{array}{c}\text { Collection and disposal } \\
\text { system (before the } \\
\text { project implementation) }\end{array}$ & $\begin{array}{c}\text { Resource recovery } \\
\text { system (new waste } \\
\text { management system) }\end{array}$ \\
\hline Household level & Storage at source & $\begin{array}{c}\text { Separation at source } \\
\text { Household composting } \\
\text { Recycling } \\
\text { Storage at source }\end{array}$ \\
\hline Neighbourhood level & Primary collection & $\begin{array}{c}\text { Primary collection } \\
\text { Sorting and pre- } \\
\end{array}$ \\
& & treatment \\
& & Recycling \\
& Composting \\
\hline City level & Secondary collection & Secondary collection \\
& Final disposal & Sorting and pre- \\
& & treatment \\
& & Recycling \\
& & Composting \\
& & Final disposal \\
\hline
\end{tabular}

collection, recycling and composting at different habitat scales, and integrating them as much as possible at the city level as shown in table 1.

The hierarchy advocated in many industrialised countries with high standards of living (giving high-priority for waste reduction), though, Surabaya's experience reveals that exploring possibilities of engaging various stakeholders in recycling organic waste through composting would alone significantly improve the situation and alleviate the problems of municipal waste management. The reason is that organics are usually the largest component of municipal solid waste in developing countries. The greatest reduction of waste collection and disposal can be achieved by diverting organic waste component from the waste stream. Composting organic waste, either at household level or on a community level, can prove to be a worthwhile effort. A typical challenge to establish a market and demand for the compost products can be overcome by integrating with other urban systems, such as urban agriculture and public parks.

Like many other cities in Indonesia, recycling and recovery activities in Surabaya is carried out by the informal sector on all levels of the municipal waste management system. Such work is done in a very labour-incentive way and for income earning. This gave an opportunity for the city to integrate the existing recycling systems in order to maximise the use of the waste as a resource, to protect and develop people's livelihoods and to reduce the costs to the city of managing the municipal waste, rather than establishing new recycling streams. 


\subsection{Integration of different stakeholder groups}

Stakeholders are all groups and individuals who have a stake, an interest and play different roles in the municipal waste management system [15]. Traditionally, solid waste management is a municipal responsibility and provided all the elements of the waste management system. However, the experience of Surabaya city has shown that cooperation and coordination between different stakeholders is essential to develop an effective and sustainable municipal management system as shown in figure 3 .

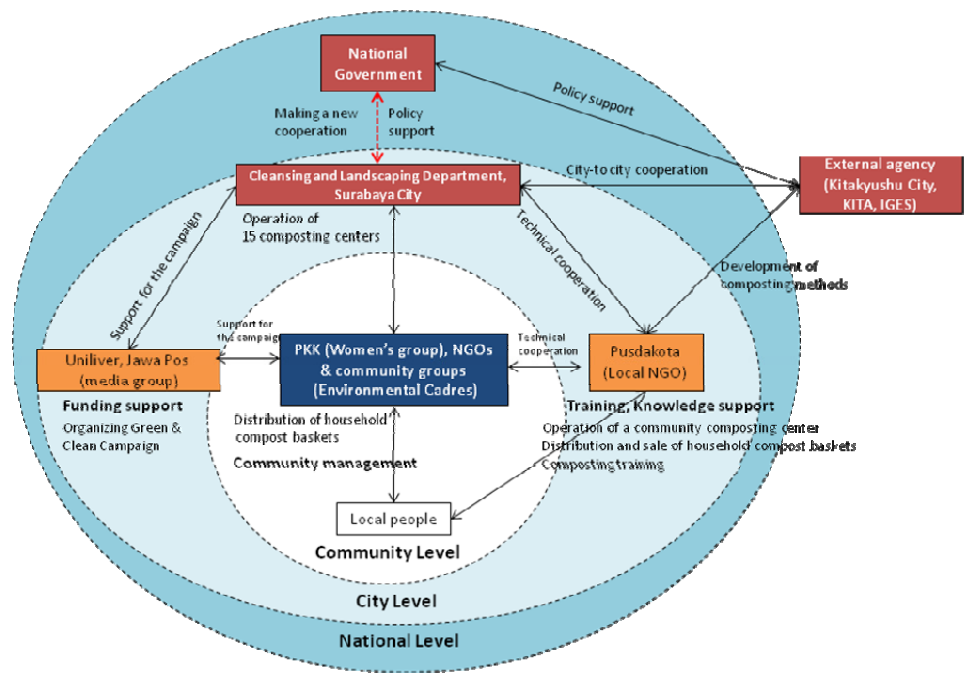

Figure 3: Stakeholder partnership in Surabaya city.

A municipal solid waste system consists of three main groups of stakeholders: the providers (who actually offer the service), the users (who are the clients) and the other external agents. Users or waste generators are key stakeholders in municipal waste management and their participation is essential for the successful implementation of municipal solid waste management programmes. They can play a range of roles, such as, waste prevention, separation at source, placing waste outside for collection, reuse, making composting using organic materials, participating in design of a waste service, participating in clean-ups, paying for waste management services, and monitoring and supervising the operation of services. Community involvement leads to more responsible behaviour, increased environmental awareness, and a higher willingness to pay among users of a waste management system. It can also lead to empowerment of groups of stakeholders that have had limited access to decision-making power and resources and build social capital within the community.

The role of community-based organisations (CBOs), NGOs, research institutes, and universities is essential in supporting communities and the informal sector, including organising, providing training, advocacy, and support 
them with research, technical and financial assistance. National and local governments can establish enabling environment for local communities and the informal sector by changing legislation and recognising them as candidates for service contracts. To involve all these groups and to address the constraints they face requires a change in the attitudes of governments and politicians and giving some incentives encouraging community participation.

\subsection{Key aspects of ISWM}

The Surabaya's experience show that technologies for municipal solid waste management need to be simple, low-cost, easy-to-follow methods, adopt to the physical environment, topography and other physical requirements, preferably locally manufactured and based on indigenous technology, geared towards efficiency and optimum utilisation of equipment. However, sustainable solid waste management is definitely not only a technical challenge. Understanding and taking into account the environmental impacts, financial and economic benefits, social and cultural aspects, and the institutional, political and legal framework, is essential for planning and implementation of a sustainable solid waste management system.

\section{Conclusion}

The key conclusion from the Surabaya case study is that a successful solution for the municipal solid waste management needs to consider all of the three aspects of ISWM. The success of the ISWM system based on the 3Rs depends on the partnerships among all stakeholders, including waste generators, private sector (formal and informal), national and local governments, and international agencies. A clear vision, political commitment and change in attitudes as well as technical, financial, legal, and institutional capacity enabled these partnerships and maximised its impact.

\section{References}

[1] UN-HABITAT, Solid Waste Management in the World's Cities, Earthscan Ltd: London and Washington, D.C., p. V, 2010.

[2] Casanova, L., Modernizing solid waste in the Asian Tigers (Key Sheet 1). Solid Waste Management in the World's Cities, ed. UN-HABITAT, Earthscan Ltd: London and Washington, D.C., pp. XXVI-XXVII, 2010.

[3] Key Note Publications Ltd, Global Waste Management Market Assessment 2007, Key Note Publication Ltd: Hampton, 2007.

[4] World Bank, What a Waste: Solid Waste Management in Asia, the World Bank: Washington, D.C., p. 1, 1999. www.worldbank.org/urban/solid_wm /erm/CWG\%20folder/uwp1.pdf

[5] UNEP, Developing Integrated Solid Waste Management Plan: Training Manual (Volume 4: ISWM Plan), UNEP: Osaka and Shiga, p. 2, 2009. 
[6] Zurbrugg, C., Drescher, S., Rytz, I., Maqsood Sinha, A. H. Md., Enayetullah, I., Decentralised composting in Bangladesh, a win-win situation for all stakeholders, Resource Conservation and Recycling, 43, pp. 281-292, 2005.

[7] Dulac, N., The Organic Waste Flow in Integrated Sustainable Waste Management: Tools for Decision-Makers-Experiences from the Urban Waste Expertise Programme (1995-2001), WASTE: Gouda, 2001.

[8] Commission on Sustainable Development, Report of the United Nations Conference on Environment and Development, Rio de Janeiro, 3-14 June 1992, vol.1, Resolutions adopted by the conference, United Nations Publication, 1992

[9] Gertsakis, J., Lewis, H., Sustainability and the Waste Management Hierarchy - A Discussion Paper, EcoRecycle: Victoria, 2004. www.cfd.mit.edu.au/content/download/189/1390/file/Sustainability\%20and $\% 20$ the $\% 20$ Waste $\% 20$ Hierarchy.pdf.

[10] Smith, P. G., Scott, J. S., Dictionary of Water and Waste Management, Elsevier: Butterworth and Heinemann, 2005.

[11] Gilbert, R., Stevenson, D., Girardet, H., Stren, R., Maling Cities Work: The Role of Local Authorities in the Urban Development, Earthscan Ltd: London, 1996.

[12] van de Klundert, A., The Sustainability of Alliances between Stakeholders in Waste Management: Using the Concept of Integrated Sustainable Waste Management - Working Paper for UWEP/CWG, 2000. www.gdrc.org/uem/waste/ISWM.pdf

[13] Anschutz, J., Ijgosse, J., Scheinberg, A., Putting ISWM to Practice, WASTE: Gouda, 2004.

[14] Anschutz, J., Keita, M., Rosario, A., Lapid, D., Rudin, V., UWEP City Case Studies, WASTE: Gouda, 2005

[15] van de Klundert, A., Anschutz, J., Integrated Sustainable Waste Management - the Concept, WASTE: Gouda, 2001.

[16] Medina, M., Community-based organics diversion, BioCycle, pp. 57-59, 2010.

[17] Silas, J., Waste Management Policies in Surabaya: An Integrated Approach, Kitakyushu Initiative: Kitakyushu, 2002. www.kitakyushu.iges.or.jp/successful_practices/solid_waste_management. html.

[18] Wilson, D. C., Presentation on collection, sorting and recycling, Regional Conference on Partnership in Municipal Solid Waste Management, ERM: UK, 2000 